\title{
Removal of Chemical Oxygen Demand in Brackish Water by Rhizophora mucronata using Reed Bed System Batch Reactor
}

\author{
Harmin Sulistiyaning Titah ${ }^{1, *}$, Ipung Fitri Purwanti ${ }^{1}$, Herman Pratikno ${ }^{2}$, Rachmi Layina Chimayati $^{1}$, and Handayanu ${ }^{2}$ \\ ${ }^{1}$ Department of Environmental Engineering, Faculty of Civil, Environmental and Geo Engineering, Sepuluh Nopember Institute of \\ Technology, Surabaya - Indonesia \\ ${ }^{2}$ Department of Ocean Engineering, Faculty of Marine Technology, Sepuluh Nopember Institute of Technology, Surabaya - Indonesia
}

\begin{abstract}
River pollution can cause coastal pollution due to many pollutants can not remove during water flow from upstream to downstream. River has a capability to do self purification to remediate many pollutans, but wastewater disposal occurred at along the river. One of pollution parameter that caused by organic pollutant was Chemical Oxygen Demand (COD). In this research, the design of reactor was adapted from reed bed system commonly used in constructed wetlands. The purpose of the study was to determine the COD removal by Rhizophora mucronata using reed bed system reactor. There were 8 reactors, with duplo replicates, namely RM15 and RM 25 for treatment with Rhizophora mucronata at $15 \%$ and $25 \%$, respectively, and RMVA15 and RMVA 25 for treatment with Rhizophora mucronata and addition of Vibrio alginolyticus, respectively. Parameter of COD was determined using digestion reactor and spectrophotometer. Based on the results, the highest removal of COD reached $82.06 \%$ after 14 days at reactor of RM15. The highest of removal COD with addition of Vibrio alginolyticus was $80.89 \%$ after Day 2 at reactor of RMVA15. In conclusion, the Rhizophora mucronata that was grown at reed bed system reactor demonstrated can be used in removing organic matter.
\end{abstract}

Keywords: bacteria; coastal pollution; mangrove; organic pollutant; reed bed system; salinity.

\section{Introduction}

The freshwater volume in the world were just around $0.5 \%$ of the total volume of water or it reached $2.84 \times 105 \mathrm{Km}^{3}$ [1]. It meant that seawater has the biggest volume in the world. River pollution can cause coastal pollution and sea pollution due to many pollutants can not remove during water flow from upstream to downstream. Although river has a capability to do self-purification to remediate many pollutants, wastewater disposal occurred along the river. Organic and inorganic pollutant was founded in rivers. Organic pollutants such us organophosphate and organochloride, inorganic pollutants such as heavy metals and nutrients. Generally, some organic pollutants that were removed by aquatic plants in wetlands system were chlorinated solvents, petroleum hydrocarbons, and explosives. However, some studies also considered other potential plants to treat other organic contaminants, such as polycyclic aromatic hydrocarbons (PAHs) and polychlorinated biphenyls (PCB) [2].

Mangroves are perennial woody plants grown in tropical and sub-tropical inter-tidal zones [3]. Mangrove can survive in a high range of salinity. Based on our previous study [4], Rhizophora mucronata can survive until salinity of $30 \%$. Mangrove plants that were grown in natural and constructed wetlands have highly efficient for adsorbing process and absorbing wastewater-borne pollutants, including inorganic compounds such as nitrogen, phosphorus, heavy metals and toxic organic pollutants [5-9]. Based on $\mathrm{Ke}$ and Tam [10], the removal efficiencies of nutrients from the wastewater in constructed mangrove wetlands ranged from 75 to $98 \%$ and this percentages of removal of metals reached $88-96 \%$. According to Tam and Wong [2], the percentage of reduction of Chemical Oxygen Demand (COD) was over $90 \%$, removal of ammonium nitrate was over 95\%, phosphorus removal percentages between 40 to $65 \%$ and very high percentage of heavy metals removal at a pilot-scale of constructed wetlands using system of sub-surface flow wetland with mixed of mangrove plants and without mangrove plant species in China. The parameter of COD usually was used to measure organic pollutant in water as the rapid indicator, The parameter of COD was a useful measurement of water quality. Generally, it was used in municipal and industrial wastewater treatment and it can indicate the efficiency of removal of organic pollutants or the treatment process performance.

The aim of this research was was to determine the Chemical Oxygen Demand (COD) removal in brackish water by Rhizophora mucronata using a reed bed system reactor with and without the addition of Vibrio alginolyticus. The design of reactor was

\footnotetext{
* Corresponding author: harminsulis@gmail.com , harmin_st@its.ac.id
} 
adapted from a reed bed system commonly used in constructed wetlands. The basic components employed in the construction of constructed wetlands were containers, plant species, and sand and gravel media in certain ratios. The other invertebrates and microbes can develop naturally during the process [3]. Vibrio is a genus of bacteria indigenous to the aquatic environment. This genus bacteria was also as a contaminant of raw or undercooked seafood. They have Gram-negative, curved colonies, rod-shaped, halophilic, and non-spore forming bacteria. These bacteria can grow in saline aquatic environments through free of living in the water and attach to animate and inanimate surfaces [11].

\section{Materials and Methods}

\subsection{Mangrove Preparation}

Rhizophora mucronata were collected from nursery of mangrove at Wonorejo, Surabaya. The age of plants was about 3 months. Figure 1 showed the mangrove acclimatization at greenhouse before mangrove was used in research.

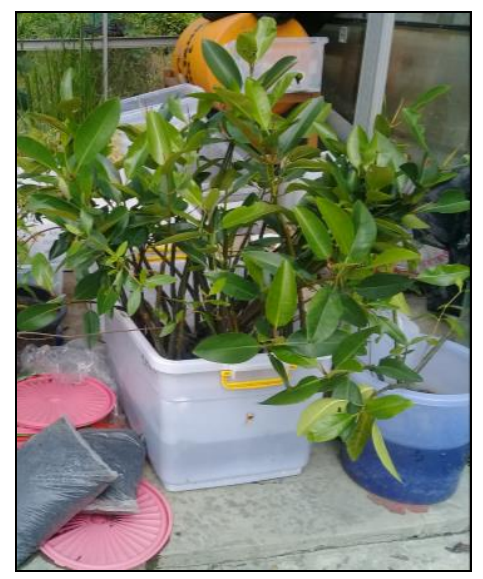

Fig. 1. Mangrove acclimatization.

\subsection{Reactor Preparation}

The plastic reactors were used with dimensions of $31.5 \times 31.5 \times 65.5 \mathrm{~cm}$. The bottom layer was a double layer of gravel with $2 \mathrm{~cm}$ and $1 \mathrm{~cm}$ of diameter. The height of gravel layer was $5 \mathrm{~cm}$. After then, the layer filled with $2 \mathrm{~L}$ of water After that, a sand layer was put with $10 \mathrm{~cm}$ of high. The saturated water in second layer was $1.8 \mathrm{~L}$. And the top layer was artificial saline water with inial salinity of $15 \%$ and $25 \%$. as high as $10 \mathrm{~cm}$ with $3 \mathrm{~L}$ of water. Figure 2 described the reed bed system reactor. There were 8 reactors, with duplo replicates, namely RM15 and RM 25 for treatment with Rhizophora mucronata at $15 \%$ and $25 \%$, respectively, and RMVA15 and RMVA 25 for treatment with Rhizophora mucronata and addition of Vibrio alginolyticus bacteria at $15 \%$ and $25 \%$, respectively.

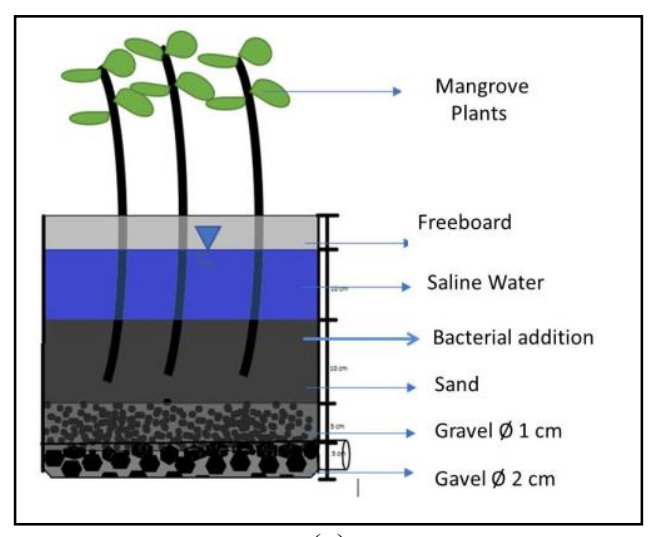

(a)

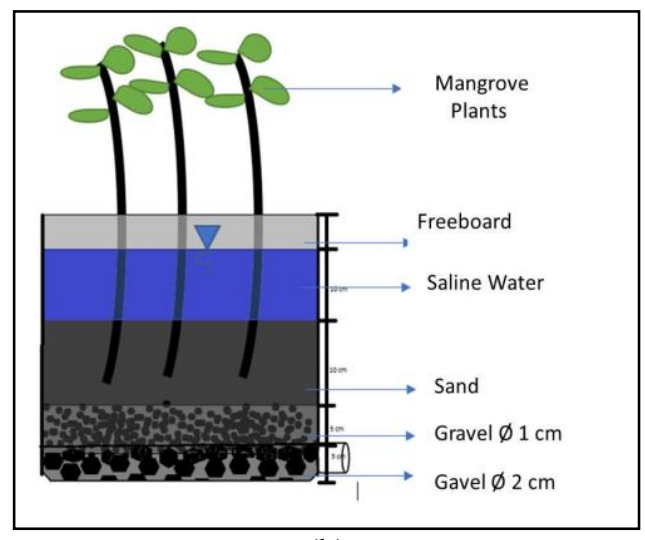

(b)

Fig. 2. A reed bed system reactor (a) with bacterial addition and (b) without bacterial addition

\subsection{Bacterial Preparation}

The bacterial requirement (Vibrio alginolyticus) was $5 \%(\mathrm{v} / \mathrm{v})$, then bacteria required $0.15 \mathrm{~L} /$ reactor. This preparation of bacteria was conducted based on our earlier research [12].

\subsection{Artificial Salinity Preparation}

The preparation of artificial salinity was conducted based on our earlier research[12].

\subsection{Parameter Analysis}

The analysis of COD parameter was conducted using a digestion reactor or COD thermo reactor, and spectrophotometer (Nova 60, Germany). The $2 \mathrm{~mL}$ of sample was put in COD vial with holding the vial at $45^{\circ}$ angle. After that, the vial was cap tightly and it was rinsed and wipe clean with paper towel. The vial was placed in the preheated COD reactor or a COD thermo reactor. The blank was prepared by repeating the steps using $2.0 \mathrm{~mL}$ distilled water. All vials were heated for 2 hours. After that, the reactor was turned off and it was waited around 20 minutes to become cool. Each of the vials was inverted several times while still warm. All vials were put into a rack and kept in the room temperature. After all, vials were 
cool, the reading process of COD concentration was conducted using a spectrophotometer.

Monitoring parameters also were determined. Those parameters were $\mathrm{pH}$ and temperature. The value of $\mathrm{pH}$ was measured using a waterproof pocket $\mathrm{pH}$ meter model HI-98107 (Hanna, USA). The temperature was determined using thermometer model HI-98501 (Hanna, USA).

Determination of bacteria population using Colony Form Unit method according to Harley and Prescott method (2002) [13]. The population bacteria determination was calculated by the number of bacteriaL colonies of sample with divide by the dilution factor. The final plates in the series should have between 25 and 250 colonies [13].

The fresh and dry weights (FW, DW) were measured for each part of the sampled plants (roots, stems, and leaves). The fresh weight was conducted as soon as possible after plants were cleaned using tissue. All of the plant parts were put in an oven at $105^{\circ} \mathrm{C}$ for 24 hours for the dry weight measurement. Lastly, the FW and DW of whole plants can be calculated.

\section{Results and Discussions}

Figure 3 showed the $\mathrm{pH}$ at each reactor during the test. Based on the data, the range of $\mathrm{pH}$ showed 5.63 7.45. The $\mathrm{pH}$ fluctuation occurred at all reactors. The increasing and decreasing $\mathrm{pH}$ can be occurred due to activities by a microorganism. However, mangrove can growth at those $\mathrm{pH}$. According to Wantasen (2013) [14], the optimal $\mathrm{pH}$ for mangrove growth was about 7.0-8.5. Based on the data, the number of Vibrio alginolyticus at reactor RMVA was higher than at reactor without Vibrio alginolyticus addition. The number of Vibrio alginolyticus population was $1.42 \mathrm{x}$ $10^{3} \mathrm{CFU} / \mathrm{mL}$ and $3.1 \times 10^{3} \mathrm{CFU} / \mathrm{mL}$ at RMVA15 and RMVA25, respectively. However, the bacterial population of Vibrio alginolyticus at the reactors without bacterial addition reached $3 \times 10^{2} \mathrm{CFU} / \mathrm{mL}$, it indicated that Vibrio alginolyticus was as an indigenous bacteria that have been growing at rhizophera of mangrove. Based on Rojas et al. (2001), Toledo et al. (1995), [15,16], bacteria of Vibrio campbelli, Vibrio aestuarianus, and Vibrio proteolyticu was found in association with several mangrove species. Some studies reported that the diazotrophs bacteria such as the genera Azotobacter, genera Sphingomonas, genera Pseudomonas, genera Desulfuromonas, genera Derxia, and genera Vibrio have been isolated and identified in mangrove rhizophere $[17,18]$.

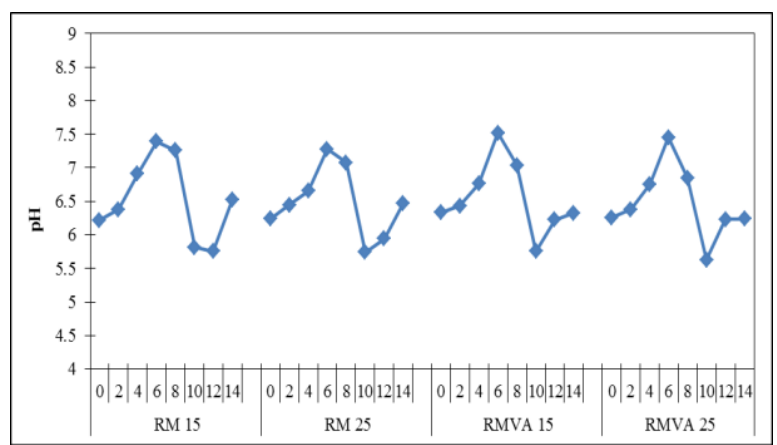

Fig. 3. Value of $\mathrm{pH}$ at each reactor

Explanation, RM15 = treatment with Rhizophora mucronata at 15 \%o, RM25 = treatment with Rhizophora mucronata at $25 \%$, RMVA15 = treatment with Rhizophora mucronata and addition of Vibrio alginolyticus bacteria at $15 \%$, and RMVA25 = treatment with Rhizophora mucronata and addition of Vibrio alginolyticus bacteria at $25 \%$.

Figure 4 showed the temperature during the test. The water temperatures range was $27.10-30.25{ }^{\circ} \mathrm{C}$. The temperature classified into normal because of the range of water temperature in the sea waters. This temperature is still reasonable for tropical waters that range between 25.6-32.3 ${ }^{\circ} \mathrm{C}$ [19]. Meanwhile, the optimum temperature range for mangrove growth is $18-30{ }^{\circ} \mathrm{C}[20]$.

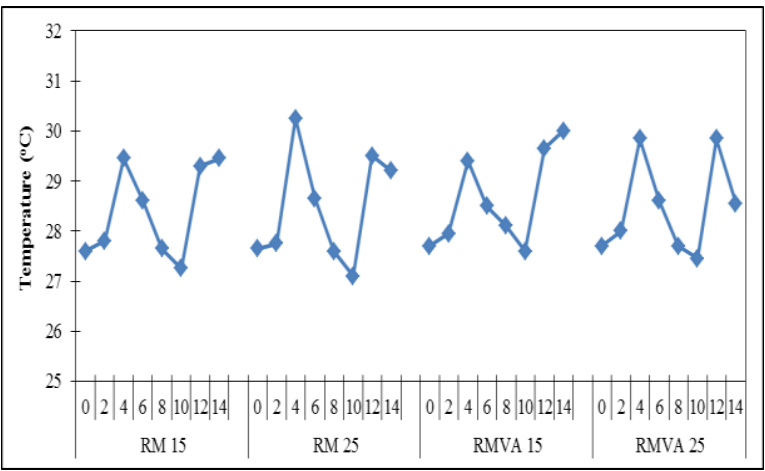

Fig. 4. Temperature at each reactor

Explanation, RM15 = treatment with Rhizophora mucronata at 15 \%o, RM25 = treatment with Rhizophora mucronata at $25 \%$, RMVA15 = treatment with Rhizophora mucronata and addition of Vibrio alginolyticus bacteria at $15 \%$, and RMVA25 = treatment with Rhizophora mucronata and addition of Vibrio alginolyticus bacteria at $25 \%$.

Figure 5 depicted the FW and DW of Rhizophora mucronata after the test. Based on the Figure, after 14 days of exposure, the DW on Rhizophora mucronata was higher at reactor of RMVA25 when compared with other reactors. The percentage of weight reduction were $50.2 ; 47.5 ; 46.5$ and $38.0 \%$ for RM15, RM25, RMVA15, AND RMVA25 respectively. It indicated that the water content in Rhizophora mucronata at reactor of RMVA25 was more stable. 


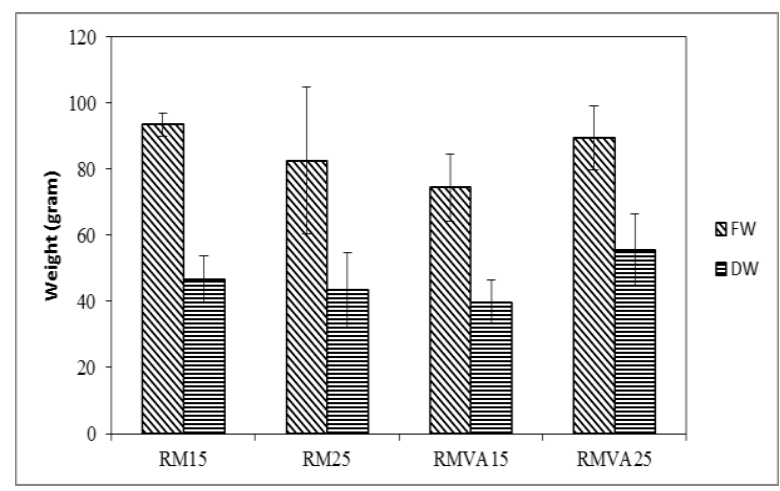

Fig. 5. FW and DW of whole plants at each reactor Explanation, $\mathrm{FW}=$ fresh weight, $\mathrm{DW}=$ dry weight, $\mathrm{RM} 15=$ treatment with Rhizophora mucronata at $15 \%$, RM25 = treatment with Rhizophora mucronata at $25 \%$, RMVA15 = treatment with Rhizophora mucronata and addition of Vibrio alginolyticus bacteria at $15 \%$, and RMVA25 = treatment with Rhizophora mucronata and addition of Vibrio alginolyticus bacteria at $25 \%$.

Figure 6 showed the percentages removal of COD at each reactor. Based on the Figure, the salinity was high so the removal of COD decreased. The highest of COD removal occurred at salinity of $15 \%$. The highest percentage of COD removal was $82.06 \%$ at initial salinity of $15 \%$ for 14 days. According to Tam and Wong [2], the initial COD that ranged between 200 to $400 \mathrm{mg} / \mathrm{L}$ can be reduced until below $20 \mathrm{mg} / \mathrm{L}$ after treated by the constructed wetland using mixed mangrove plant and non-mangrove plant. It showed much lower than the discharge standard of $50 \mathrm{mg} / \mathrm{L}$. The average removal percentage of COD was over $90 \%$. So, the selection of wetland plants for constructed wetlands is an important thing due to the different species of plants that can show variation of pollutant removal efficiency [2].

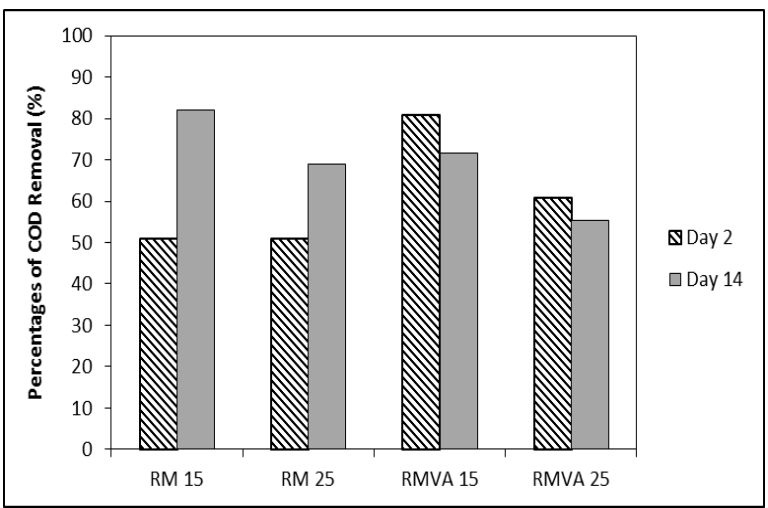

Fig. 6. Percentages removal of COD at each reactor Explanation, RM15 = treatment with Rhizophora mucronata at 15 $\%$, RM25 = treatment with Rhizophora mucronata at $25 \%$, RMVA15 = treatment with Rhizophora mucronata and addition of Vibrio alginolyticus bacteria at $15 \%$, and RMVA25 = treatment with Rhizophora mucronata and addition of Vibrio alginolyticus bacteria at $25 \%$.

The addition of Vibrio alginolyticus can increase the removal of COD on Day 2, however, it showed decreased of COD removal at Day 14. The highest of removal COD with addition of Vibrio alginolyticus was $80.89 \%$ on Day 2. It indicated that bacteria can enhanced the removal of COD within the make time of process was shorter.
According to Mahmood et al. [3], the process of organic pollutants by plants can be predicted through the four mechanisms, first, those organic pollutants were uptaken by plants directly, and then accumulation, and metabolism of pollutants in plant tissues or it was called as detoxification. Second mechanism was transpiration of volatile organic hydrocarbons through leaves or it was known as avoidance. Third mechanism was the exudates releasing from the plant roots that can stimulate microbial activity at the rhizhopera and biochemical transformations process or it was called as chelation. The last mechanism, the enhance of the mineralization process of pollutants in rhizosphere due to the presence of mycorrhizal fungi and microbial consortia associated with the plant root surfaces.

\section{Conclusion}

The highest removal of COD reached $82.06 \%$ after 14 days at reactor of RM15. However, the highest of removal COD with addition of Vibrio alginolyticus was $80.89 \%$ after Day 2 at reactor of RMVA 15 . The addition of Vibrio alginolyticus can increase the COD removal although the COD removal decreased on Day 14. In conclusion, the Rhizophora mucronata that was grown at a reed bed system reactor can be used in removing organic matter for organic pollution in brackish water.

The author would like to thank KemenristekDIKTI (Ministry of Research, Technology and Higher Education, Republic of Indonesia) through a scheme of Penelitian Terapan Unggulan Perguruan Tinggi - second year research, PDUPT 2019 for funding this research with No of contract, 5/E1/KP.PTNBH/2019 and No. 920/PKS/ITS/2019.

\section{References}

1. M.R. Singh, G.A. Gupta. Water Pollution Sources, Effects and Control (2016)

2. Q. Mahmood, A. Pervez, B.S. Zeb, H. Zaffar, H. Yaqoob, M. Waseem, Zahidullah, S. Afsheen, BioMed Res. Int., 1-19 (2013)

3. N.F Tam, Y. Wong, 2014 4th International Conference on Future Environment and Energy, IPCBEE 61 (2014)

4. H.S. Titah, I.F. Purwanti, H. Pratikno, R.L. Chimayati, Handayanu, J.of Ecol. Eng. 20(3), 126134 (2019)

5. J.E. Zhang, J.L. Liu, Y. Quyang, B.W. Liao, B.L. Zhao. Ecol. Eng. 36, 807-812 (2010)

6. Y.M. Su, Y.F. Lin, S.R. Jing, P.C.L. Hou, Mar. Pollut. Bull. 62, 1455-1463 (2011)

7. M. Leis, R. Pryor, L. Wilking, Environ. Pollut. 159, 2328-2346 (2011) 
8. Y. Wu, A. Chung, N. Pi, N.F.Y. Tam, M.H. Wong. Ecol. Eng. 34, 137-146 (2008)

9. Q. Yang, N.F.Y. Tam, Y.S. Wong, T.G. Luan, W.S. Su, C.Y. Lan, P.K.S. Shin, S.G. Cheung, Mar. Pollut. Bull. 57, 735-743 (2008)

10. L. Ke, N.F.Y. Tam, Toxicity and Bioavailability of Heavy Metals and Hydrocarbons in Mangrove Wetlands and Their Remediation. In: M.H. Wong (Ed.), Environmental Contamination-Health Risks, Bioavailability and Bioremediation, Taylor and Francis, CRC Press., 371-392 (2012)

11. K. Arunagiri, T. Sivakumar, T. Murugan, Asian J. Pharm Clin Res. 9(1), 229-231 (2016)

12. R.L. Chimayati, H.S. Titah, J. of Ecol. Eng. 20(4), 84-93 (2019)

13. J.P. Harley, L.M. Prescott, Laboratory Exercises in Microbiology Fifth Edition. McGraw-Hill Companies, Texas (2002).

14. Wantasen U S. J. Platax 1, 204-209 (2013)

15. A. Rojas, G. Holguin, B.R. Glick, and Y. Bashan, FEMS Microbiol. Ecol. 35, 181-187 (2001)

16. G. Toledo, Y. Bashan, A. Soeldner, Can. J. Microbiol. 41, 1012-1020 (1995)

17. A.L. Flores-Mireles, S.C. Winans, G. Holguin, Appl. Environ. Microbiol. 73, 7308-7321 (2007)

18. Y. Zhang, J. Dong, Z. Yang, S. Zhang, Y. Wang. Arch. Microbiol. 190, 19-28 (2008)

19. J.W. Nybakken, Marine Biology: an Ecological Approach (San Francisco: Benjamin Cummings). (2001)

20. A.D. Setyawan, A. Susilowati, Sutarno, Genetic Biodiversity, Species and Mangrove Ecosystem in Java, Surakarta: Sebelas Maret University (2002) 